\title{
Phosphorus Sorption Behavior of Torrefied Agricultural Byproducts under Sonicated Versus Non-Sonicated Conditions
}

\author{
Jehangir H. Bhadha ${ }^{1}$, Stephen P. Jennewein ${ }^{1} \&$ Raju Khatiwada ${ }^{1}$ \\ ${ }^{1}$ Soil \& Water Sciences Department, University of Florida, Everglades Research \& Education Center, Belle \\ Glade, Florida-33430, USA \\ Correspondence: Jehangir H. Bhadha, Soil \& Water Sciences Department, University of Florida, Everglades \\ Research \& Education Center, Belle Glade, Florida-33430, USA. Tel: 1-561-993-1711. E-mail: jango@ufl.edu
}

Received: June 16, 2017 Accepted: July 19, 2017 Online Published: July 29, 2017

doi:10.5539/sar.v6n4p1 URL: https://doi.org/10.5539/sar.v6n4p1

\begin{abstract}
The application of agrichar derived from organic feedstocks has the potential to improve soil fertility and crop production by providing major nutrients like phosphorus $(\mathrm{P})$ to the crop, and in some cases also reducing $\mathrm{P}$ leaching. The effect of agrichar on the leaching of $\mathrm{P}$ in soils is not uniform and can vary depending on the type of agrichar and amount applied. The objective of this study was to (i) evaluate the behavior of four agrichars (rice hulls RH, palm fronds PF, horse bedding $\mathrm{HB}$, and bagasse $\mathrm{BG}$ ) for their ability to retain/release $\mathrm{P}$ and (ii) determine the effect of wet sonication on $\mathrm{P}$ sorption behavior. The feedstocks were torrefied at $500{ }^{\circ} \mathrm{C}$ using a top-lit updraft gasifier and used in multiple batch incubation experiments to evaluate equilibrium phosphorus concentration, maximum $\mathrm{P}$ sorption capacity $\left(\mathrm{S}_{\max }\right)$, and adsorption/desorption potential. Both, RH $\left(12.6 \mathrm{~g} \mathrm{~kg}^{-1}\right)$ and $\mathrm{HB}\left(11.5 \mathrm{~g} \mathrm{~kg}^{-1}\right)$ contained 10-15 times higher total P concentration than PF and BG, rendering RH and $\mathrm{HB}$ as potentially suitable products to be used as soil amendments. However, this initial P content of the agrichar seemed to have an overriding effect on the P sorption behavior of the agrichar. PF had $S_{\max }$ of $676( \pm 127) \mathrm{mg}$ $\mathrm{kg}^{-1}$ for the non-sonicated agrichar, and $237( \pm 91) \mathrm{mg} \mathrm{kg}^{-1}$ following sonication. There was significant increase in CEC for PF and BG agrichar upon sonication. PF agrichar increased from $27( \pm 3) \mathrm{cmol}_{\mathrm{c}} \mathrm{kg}^{-1}$ to $41( \pm 4) \mathrm{cmol}_{\mathrm{c}}$ $\mathrm{kg}^{-1}$ with sonication. Similarly, BG agrichar CEC increased from $21( \pm 2) \mathrm{cmol}_{\mathrm{c}} \mathrm{kg}^{-1}$ to $45( \pm 5) \mathrm{cmol}_{\mathrm{c}} \mathrm{kg}^{-1}$ with sonication. Initial total $\mathrm{P}$ and $\mathrm{Ca}$ concentration and their ratios was found to play significant roles on $\mathrm{P}$ adsorption and desorption. Major cations like $\mathrm{Ca}, \mathrm{Fe}, \mathrm{Al}$ and $\mathrm{Mn}$ are found to act as active sorption site for phosphorus controlling its fate and mobility along with compounding effects of other physicochemical parameters.
\end{abstract}

Keywords: agrichar, biochar, phosphorus, sonication, adsorption, desorption

\section{Introduction}

Developing effective technologies to retain nutrients in soils is important because they can increase soil fertility and reduce repeated fertilizer application cost. Depleted soils are regularly amended with products that provide nutrients and organic matter. Land application of biochar, sometimes referred to as "agrichar", has received attention over the past decade to improve soil properties and thus improve overall soil quality (Van Zwieten et al., 2009). Enhancing soil properties such as water holding capacity, organic matter content, and nutrient retention dynamics are key to improving soil quality. The application of agrichar derived from organic feedstocks has the potential to improve soil fertility and crop production by reducing the leaching of nutrients, and in most cases by supplying nutrients to the plants (Ding et al., 2016; Gao, Hoffman-Krull, Bidwell, \& DeLuca, 2016; Glaser, Lehmann, \& Zech, 2002; Madiba, Solaiman, Carson, \& Murphy, 2016; Major, Rondon, Molina, Riha, \& Lehmann, 2010; Ngatia, Hsieh, Nemours, Fu, \& Taylor, 2017; Randolph et al., 2017).

The application of char also has the potential to immobilize nutrients, limiting uptake by plants and reducing nutrient leaching in soils (Ippolito, Ducey, Cantrell, Novak, \& Lentz, 2016). The effect of agrichar on the leaching of nutrients such as phosphorus (P) in soils is not uniform and varies by agrichar and nutrient type (Y. Yao, Gao, Zhang, Inyang, \& Zimmerman, 2012). When used as a soil amendment, it would be useful to understand its $\mathrm{P}$ sorption behavior, and also ascertain the sorption response to other agrichar engineering treatments such as sonication. The nature of change in soil characteristics following char application is dependent on native biogeochemistry (Streubel et al., 2011; Zhu, Peng, \& Huang, 2015), feedstock characteristics (Windeatt et al., 2014), temperature of torrefaction, inherent levels of major cation, anion 
absorption sites (Uchimiya, Wartelle, Klasson, Fortier, \& Lima, 2011) and post treatment (Azargohar \& Dalai, 2008; Rajapaksha et al., 2016; Ying Yao, Gao, Chen, \& Yang, 2013). Therefore, in order to develop more effective agrichar amendments it would be useful to understand the $\mathrm{P}$ sorption behavior, and response to sonication, prior to its use as a soil amendment. Sonication is the act of applying sound to agitate particles in a sample, for various purposes. Ultrasonic frequencies $(>20 \mathrm{kHz})$ are usually used, leading to the process also being known as ultrasonication. The premise of sonicating the agrichars in this study was to evaluate its sorption behavior as a result of it.

Engineered or "designer" agrichar is a commonly used term to indicate application-based modifications to an existing agrichar. Typically, modifications to produce engineered agrichar are likely to enhance the sorption capacity of agrichar and its applications for environmental remediation (Rajapaksha et al., 2016). Agrichar sorption capacity enhancement can be achieved by numerous methods. For example chemically, by acid/base treatments or chemical oxidation (Lin, Munroe, Joseph, Henderson, \& Ziolkowski, 2012; Vithanage et al., 2015), modification of functional groups (Qian, Kumar, Zhang, Bellmer, \& Huhnke, 2015), treatment with organic solvents (Jing, Wang, Liu, Wang, \& Jiang, 2014), coating of biochar. It can also be achieved physically, either by steam activation (Manya, 2012; Rajapaksha et al., 2015), gas purging (X. Zhang et al., 2013; X. N. Zhang, Mao, Jiao, Shang, \& Han, 2014), or sonication (Lim \& Okada, 2005).

The objective of this study was to (i) evaluate the behavior of four agrichars (rice hulls, palm fronds, horse bedding, and bagasse) for their ability to retain/release $\mathrm{P}$ and (ii) determine the effect of wet sonication on $\mathrm{P}$ sorption behavior. Some of the parameters used to evaluate the four agrichars were total $\mathrm{P}$ concentration, $\mathrm{pH}$, leaching potential, total cation concentration, cation exchange capacity (CEC), equilibrium phosphorus concentration (EPC), maximum P sorption capacity $\left(S_{\max }\right)$, and adsorption/desorption potential. Results from this study will be useful in understanding how these products behave if used as a soil amendment on P-depleted soils.

\section{Material and Methods}

Locally available agricultural products from Everglades Agricultural Area were used as a source of agrichar. Four organic feedstocks, namely rice hulls (RH), palm fronds (PF), horse bedding (HB), and bagasse (BG) were selected and converted to agrichar using a custom designed Top-lit Updraft (TLUD) gasifier (Bhadha, Jennewein, Sanchez, \& Lang, 2014). RH was provided by Sem Chi Rice Products Corporation as a byproduct after the rice grains have been separated. PF was supplied by the City of Wellington Solid Waste Authority. HB was collected from the Palm Beach Polo Golf and Country Club, Wellington, FL. BG was obtained from Sugar Cane Growers Cooperative of Florida in Belle Glade, FL. The feedstocks were torrefied at $500{ }^{\circ} \mathrm{C}$ in atmospheric conditions. After the feedstock had been charred in the TLUD it was purged with nitrogen to prevent flash combustion and foster cooling. Then, two batches of $20 \mathrm{~g}$ of agrichar were placed in beakers containing $400 \mathrm{ml}$ deionized water and left for 4-days. One batch was sonicated while the other was not. After 4-days, the non-sonicated samples were filtered through a Whatman \#2 filter paper ( 8 - $\mu \mathrm{m}$ pore size), while the samples to be sonicated were held in an ultrasonic sonication bath (Fisher Scientific) at $40 \mathrm{kHz}$ for 4-hours at $25{ }^{\circ} \mathrm{C}$. The filtrates were collected and analyzed for total phosphorus (TP) using 12.1 M hydrochloric acid digestion (Mylavarapu \& Moon, 2002) and major cations (Calcium-Ca, Magnesium-Mg, Iron-Fe and Aluminum-Al). The elemental concentration was measured using an inductively coupled plasma mass spectrometer (ICP-MS). Both sonicated and non-sonicated samples were oven dried at $50{ }^{\circ} \mathrm{C}$ and stored for conducting further experiments. The $\mathrm{pH}$ of the dried agrichar (non-sonicated and sonicated) was determined using a 2:1 water to agrichar mixture (Thomas, 1996) using a Thermo Orion pH meter (model 720 Aplus). Cation exchange capacity (CEC) was estimated in triplicate using the ammonium acetate $(\mathrm{pH} 7)$ method (Sumner \& Miller, 1996) and ammonium concentrations were analyzed with flow injection analysis on a Lachat analyzer (QuikChem Method 10-107-06-2-A. Hach Company, Loveland, $\mathrm{CO}$ ). The ammonium concentration in $\mathrm{mg} \mathrm{L}^{-1}$ was converted to its equivalent on $\mathrm{cmol}_{\mathrm{c}} \mathrm{kg}^{-1}$ agrichar.

Dried agrichar was used to conduct the EPC experiment. Equilibration was performed under aerobic conditions, where $1 \mathrm{~g}$ of agrichar was placed in a 50-ml centrifuge tube and treated with $30 \mathrm{ml}$ of $0.01 \mathrm{M} \mathrm{KCl}$ solution containing increasing $\mathrm{P}$ concentration $\left(0,0.5,1,5,10\right.$ and $\left.30 \mathrm{mg} \mathrm{P} \mathrm{L}^{-1}\right)$ and shaken for $24 \mathrm{~h}$ at low velocity on a reciprocal shaker. The samples were then centrifuged for $12 \mathrm{~min}$ at $6000 \mathrm{rpm}$ and filtered through $8-\mu \mathrm{m}$ filter paper. Filtrates were analyzed for TP using 12.1 M hydrochloric acid digestion (Mylavarapu \& Moon, 2002) and measured using ICP-MS. Any $\mathrm{P}$ not present in the solution was assumed to be adsorbed by the agrichar. Concentration recovery from samples equilibrated with $0 \mathrm{mg} \mathrm{P} \mathrm{L}^{-1}$ was used to estimate water soluble $\mathrm{P}$ (WSP) (Reddy, Wang, DeBusk, Fisher, \& Newman, 1998).

Agrichar phosphate and the EPC were calculated as follows: 


$$
S^{\prime}=\left[\left(C_{0} \times V\right)-\left(C_{e q} \times V\right)\right] M^{-1}
$$

where $\mathrm{S}^{\prime}$ is the $\mathrm{P}$ sorbed by agrichar $\left(\mathrm{mg} \mathrm{kg}^{-1}\right), \mathrm{C}_{0}$ is the concentration of $\mathrm{P}$ added $\left(\mathrm{mg} \mathrm{L}^{-1}\right), \mathrm{V}$ is the volume of liquid, $\mathrm{C}_{\mathrm{eq}}$ is the concentration of $\mathrm{P}$ in the solution after $24 \mathrm{~h}\left(\mathrm{mg} \mathrm{L}^{-1}\right)$, and $\mathrm{M}$ is the mass of dry agrichar $(\mathrm{kg})$. The total amount of P retained by the agrichar was calculated as

$$
S=S^{\prime}+S_{0}
$$

where $\mathrm{S}$ is the total amount of $\mathrm{P}$ sorbed $\left(\mathrm{mg} \mathrm{kg}^{-1}\right)$ and $\mathrm{S}_{0}$ is the initial agrichar $\mathrm{P}$ present in adsorbed phase (mg $\mathrm{kg}^{-1}$ ). The $\mathrm{S}_{0}$ was estimated by using a least squares fit of $\mathrm{S}^{\prime}$ measured at low equilibrium concentrations $\mathrm{C}_{\mathrm{eq}}$. At these concentrations, the relationship between $\mathrm{S}^{\prime}$ and $\mathrm{C}_{\mathrm{eq}}$ is usually linear (Rao \& Davidson, 1979) and described by the following equation:

$$
S^{\prime}=K_{d} C_{e q}-S_{0}
$$

where $S_{0}$ is the $y$-axis intercept representing the initial agrichar $P$ present in the adsorbed phase $\left(\mathrm{mg} \mathrm{kg}^{-1}\right)$ and $\mathrm{K}_{\mathrm{d}}$ is the linear adsorption coefficient $\left(\mathrm{L} \mathrm{kg}^{-1}\right)$. Equilibrium $\mathrm{P}$ concentration is defined as the concentration of $\mathrm{P}$ in solution where adsorption and desorption are the same (i.e., $\mathrm{S}^{\prime}=0$ ). Thus,

$$
C_{e q}=S_{0} K_{d}^{-1}
$$

where $\mathrm{C}_{\mathrm{eq}}$ is the $\mathrm{EPC}\left(\mathrm{mg} \mathrm{L}^{-1}\right)$.

Maximum $P$ sorption capacity $\left(\mathrm{S}_{\max }\right)$ was measured by adding $2 \mathrm{~g}$ of the agrichar (non-sonicated and sonicated) in an Erlenmeyer flask into which $0.1 \mathrm{~L}$ of $100 \mathrm{mg} \mathrm{P} \mathrm{L}^{-1}$ solution was added and left to equilibrate for 28-days. After which the solutions were filtered and the filtrates were analyzed for TP.

$$
S_{\max }=\frac{\left(C_{1}-C_{0}\right) V_{0}}{M_{0}} \times 10^{6}
$$

where $\mathrm{C}_{1}$ corresponds to the final $\mathrm{P}$ concentration in solution $\left(\mathrm{mg} \mathrm{L}^{-1}\right), \mathrm{C}_{0}$ corresponds to the initial $\mathrm{P}$ concentration of solution ( $\left.100 \mathrm{mg} \mathrm{L}^{-1}\right) ; \mathrm{V}_{0}$ corresponds to the initial volume of solution $(0.1 \mathrm{~L}) ; \mathrm{M}_{0}$ corresponds to the initial mass of the agrichar $(2 \mathrm{~g}) ; 10^{6}$ corresponds to unit conversion. The experiment was conducted in triplication.

Phosphorus adsorption/desorption potential was measured by adding $2 \mathrm{~g}$ of agrichar (non-sonicated and sonicated) to an Erlenmeyer flask into which we added $0.2 \mathrm{~L}$ of $100 \mathrm{mg} \mathrm{P} \mathrm{L}^{-1}$ solution was added. The flasks were shaken for 1-hour and allowed to equilibrate; subsequently $5 \mathrm{ml}$ water samples were collected at $0,1,6$, 24-hour, 4, 14, 28, and 57-day intervals. The samples were filtered $(8-\mu \mathrm{m})$ and analyzed for TP. Adsorption/desorption potential was estimated by plotting concentration in solution over time.

\section{Results and Discussion}

\subsection{Characteristics of Agrichars}

Agrichars data for various parameters are presented in Table 1. $\mathrm{pH}$ for all the agrichars was circum-neutral except for the HB agrichar. $\mathrm{HB}$ agrichar had greatest $\mathrm{pH}$ as compared to other agrichars. The greater $\mathrm{pH}$ may be attributed to contribution from inherent higher $\mathrm{pH}$ of horse manure (Castillo, Benito, \& Fernandez, 2003; Perez-Esteban, Escolastico, Masaguer, \& Moliner, 2012), associated with the high calcium-magnesium based diet likely being fed to horses. RH agrichar had greatest total $\mathrm{P}$ concentration followed by HB agrichar. PF and BG agrichars had nearly 10-15 fold less total $\mathrm{P}$ as compared to HB and RH. Cation exchange capacity values for both sonicated and non-sonicated HB agrichar samples was $39( \pm 4) \mathrm{cmol}_{\mathrm{c}} \mathrm{kg}^{-1}$ showing no effect of sonication for HB agrichar. Similarly, RH agrichar had CEC of nearly $33( \pm 3) \mathrm{cmol}_{\mathrm{c}} \mathrm{kg}^{-1}$ for sonicated and non-sonicated samples. There was significant increase in CEC for PF and BG agrichar upon sonication. PF agrichar had CEC of $27( \pm 3) \mathrm{cmol}_{\mathrm{c}} \mathrm{kg}^{-1}$ for non-sonicated samples, which increased to $41( \pm 4) \mathrm{cmol}_{\mathrm{c}} \mathrm{kg}^{-1}$ with sonication. Similarly, BG agrichar had CEC of $21( \pm 2) \mathrm{cmol}_{\mathrm{c}} \mathrm{kg}^{-1}$ for non-sonicated samples, which increased to $45( \pm 5) \mathrm{cmol}_{\mathrm{c}} \mathrm{kg}^{-1}$ with sonication. The sonication of samples for PF and BG agrichar might have resulted in breakdown of agrichars leading to increase in specific surface area and thus more exchange sites contributing to higher CEC. $\mathrm{HB}$ and RH agrichar are relatively difficult to break because of material texture as compared to PF and BG agrichars. 
Table 1. Characteristics of various agrichars

\begin{tabular}{lllllllll}
\hline Agrichar type & $\mathbf{p H}$ & $\begin{array}{l}\mathbf{T P} \\
\left(\mathbf{m g ~ k g} \mathbf{~}^{-1}\right)\end{array}$ & $\begin{array}{l}\mathbf{C E C} \\
\left(\mathbf{c m o l} \mathbf{~ k g}^{-1}\right)\end{array}$ & $\begin{array}{l}\mathbf{C a} \\
\left(\mathbf{m g ~ k g}^{-1}\right)\end{array}$ & $\begin{array}{l}\mathbf{M g} \\
\left(\mathbf{m g ~ k g}^{-1}\right)\end{array}$ & $\begin{array}{l}\mathbf{F e} \\
\left(\mathbf{m g ~ k g}^{-1}\right)\end{array}$ & $\begin{array}{l}\mathbf{A l} \\
\left(\mathbf{m g ~ k g}^{-1}\right)\end{array}$ & $\mathbf{R e m a r k s}$ \\
\hline RH-nonsonicated & 6.79 & 12601 & $33.19( \pm 3)$ & 6584 & 6195 & 1054 & 285 & \\
RH-sonicated & 6.86 & 11501 & $32.58( \pm 3)$ & 7790 & 7141 & 2374 & 529 & $(\mathrm{Ca}, \mathrm{Mg}, \mathrm{Fe}, \mathrm{Al}) \uparrow$ \\
PF-nonsonicated & 7.24 & 1322 & $27.11( \pm 3)$ & 25069 & 1271 & 1184 & 1475 & \\
PF-sonicated & 7.05 & 789 & $41.19( \pm 4)$ & 31862 & 2100 & 983 & 933 & $(\mathrm{Ca}, \mathrm{Mg}) \uparrow(\mathrm{Fe}, \mathrm{Al}) \downarrow$ \\
HB-nonsonicated & 8.03 & 10469 & $38.89( \pm 4)$ & 41314 & 5949 & 705 & 1855 & \\
HB-sonicated & 7.93 & 9588 & $38.56( \pm 4)$ & 40627 & 5818 & 873 & 1915 & $(\mathrm{Ca}, \mathrm{Mg}) \downarrow(\mathrm{Fe}, \mathrm{Al}) \uparrow$ \\
BG-nonsonicated & 6.75 & 1406 & $20.85( \pm 2)$ & 4645 & 839 & 339 & 84 & \\
BG-sonicated & 7.16 & 614 & $43.49( \pm 4)$ & 16619 & 2379 & 1030 & 297 & $(\mathrm{Ca}, \mathrm{Mg}, \mathrm{Fe}, \mathrm{Al}) \uparrow$ \\
\hline
\end{tabular}

Agrichars: BG-bagasse, HB-horse bedding, PF- palm fronds, RH-rice hull

$\mathrm{TP}=$ Total phosphorus, $\mathrm{CEC}=$ Cation exchange capacity, $\mathrm{Ca}$-Calcium, Mg-Manganese, Fe-Iron, Al-Aluminum

Sonication effects on major cations $(\mathrm{Ca}, \mathrm{Mg}, \mathrm{Fe}$ and $\mathrm{Al})$ content is shown in Table 1. For nonsonicated samples, $\mathrm{HM}$ had greatest total Ca content $\left(40 \mathrm{~g} \mathrm{~kg}^{-1}\right)$ followed by PF $\left(25 \mathrm{~g} \mathrm{~kg}^{-1}\right), \mathrm{RH}\left(6.5 \mathrm{~g} \mathrm{~kg}^{-1}\right)$ and BG. $\left.4.6 \mathrm{~g} \mathrm{~kg}^{-1}\right)$. RH had greatest Mg content followed by HM, PF and BG. PF had greatest Fe content followed by RH, HM and BG. Similarly, HM had greatest Al content followed by PF, RH and BG. Sonication increased total $\mathrm{Ca}$ and $\mathrm{Mg}$ for all samples except HM agrichar. Fe and Al content increased for all agrichars except PF. The results taken as whole suggest overall increase of major cations content due to sonication which might be due to solubilization and leaching of other material from agrichars increasing overall mass to volume ratio. Sonication beaks down the materials making new sites initially un-accessible for water to react with and solubilize. Water soluble $\mathrm{P}$ concentration of agrichars is presented in Figure 1. RH agrichar had greatest water soluble P concentration ( 10 fold higher than others) followed by HB, PF and BG agrichars for both sonicated and non-sonicated samples. Despite higher initial total P for HB agrichar, water soluble P was nearly 10 fold less as compared to RH agrichar thus indicating that total $\mathrm{P}$ is a poor predictor of available $\mathrm{P}$ in this case. Sonication resulted in net increased soluble $\mathrm{P}$ released to solution. Sonication has been widely used to enhance mixing and reduce mass-transfer limitation at the liquid/solid interface (W. Y. Chen et al., 2014) and could expose cluster of graphene and graphene oxide in biochar forming graphene and graphene oxide platelets resulting in net increase of surface area of contact (Stankovich et al., 2006). Sonication has been found to enhance release of P from activated sludge (Wang, Qiu, Lu, \& Ying, 2010).

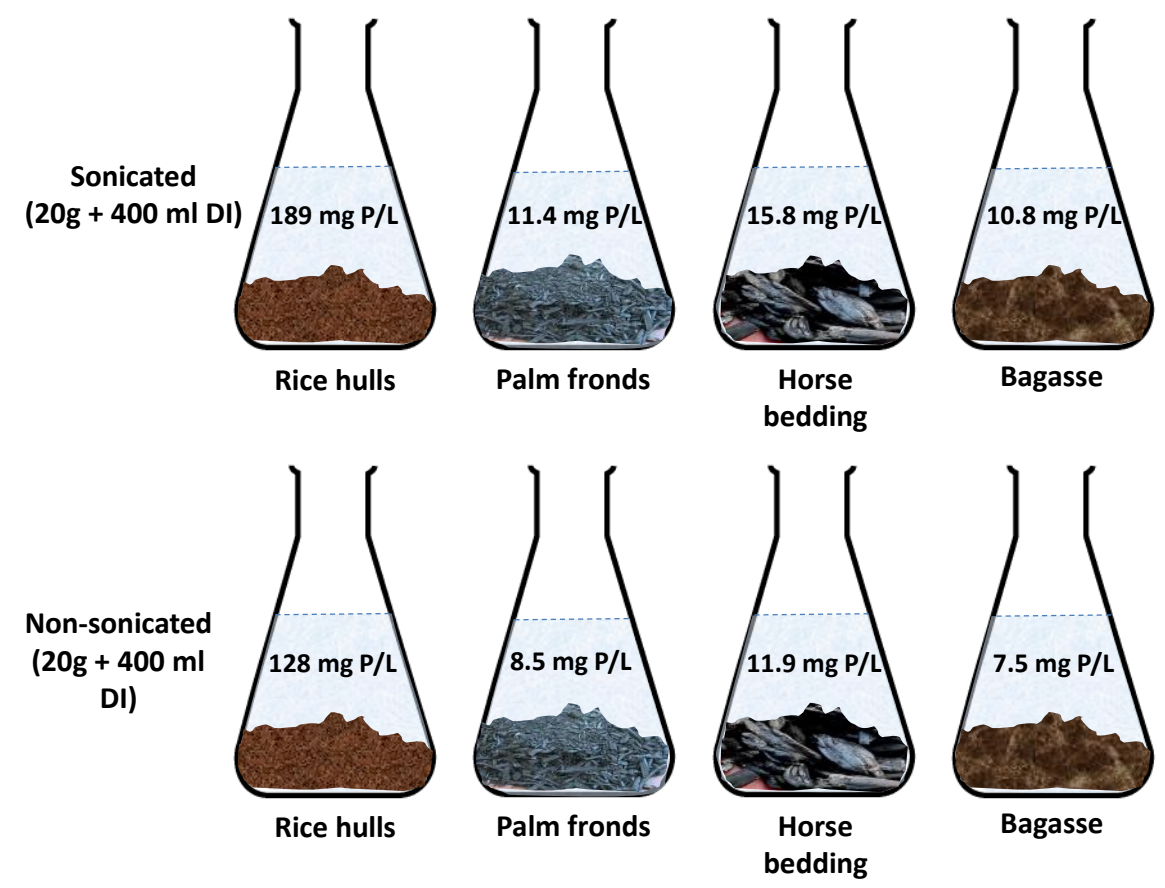

Figure 1. Water soluble phosphorus concentration of non-sonicated and sonicated agrichars 


\subsection{Equilibrium Phosphorus Concentration (EPC) of Agrichars}

Equilibrium phosphorus concentration (EPC) of agrichars are presented in Figure 2. RH had the greatest EPC (246 mg L $\mathrm{m}^{-1}$ ) followed by PF, BG and HB agrichars for non-sonicated samples. For sonicated samples, RH had greatest EPC $\left(174 \mathrm{mg} \mathrm{L}^{-1}\right)$ followed by BG, HB and PF agrichars. RH agrichar EPC was nearly 11 fold higher than other agrichars. Sonication resulted in overall decrease in EPC for all agrichars except BG, which showed increased EPC with sonication. Since RH agrichar had higher EPC than that of the aqueous system, it is likely a P source than P sink. RH might make for a good soil amendment in P- depleted soils; yet would not be the best amendment to retain P applied during fertigation. Additions of agrichar with EPC greater than that of soil was found not to contribute to P retention at environmentally relevant solution P concentrations (Dari et al., 2016).

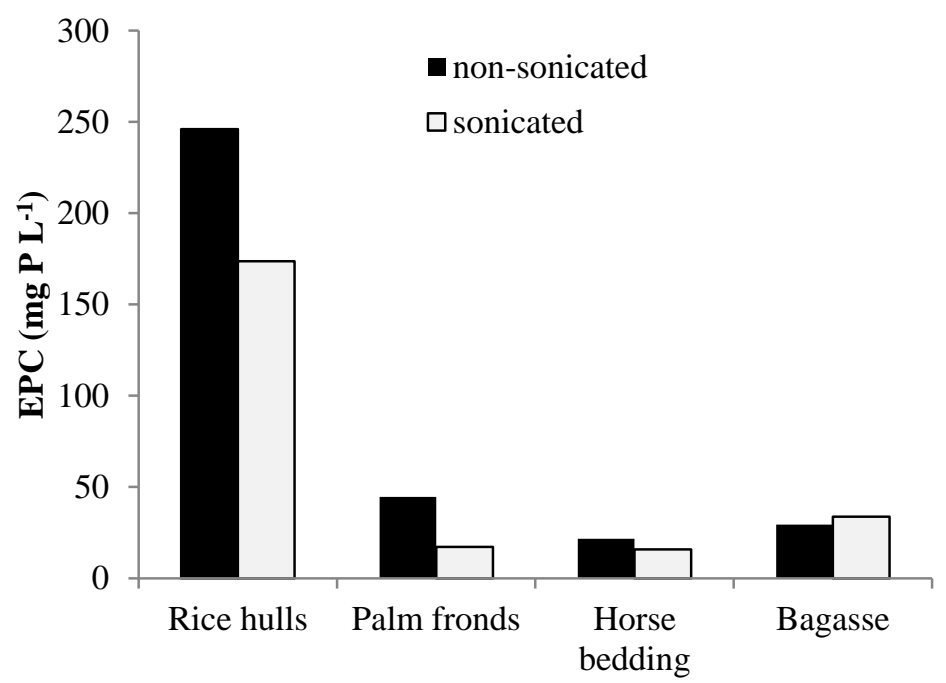

Figure 2. Equilibrium phosphorus concentration (EPC) of agrichars for non-sonicated and sonicated agrichars

\subsection{Maximum $P$ sorption Capacity $\left(S_{\max }\right)$}

Maximum $P$ sorption capacity of various agrichar materials is shown in Figure 3. Positive $S_{\max }$ indicates that the agrichar has the potential to adsorb $\mathrm{P}$; whereas a negative $\mathrm{S}_{\max }$ simply means that the agrichar has no capacity to adsorb $\mathrm{P}$, and would in fact desorbed $\mathrm{P}$ when added to $100 \mathrm{mg} \mathrm{L}^{-1}$ of $\mathrm{P}$ in solution. PF and HB showed an inherent capacity to sorb P, RH and BG both showed no capacity to retain additional P. RH agrichar had the least sorption capacity of $-2480( \pm 124) \mathrm{mg} \mathrm{kg}^{-1}$ non-sonicated and $-2629( \pm 101) \mathrm{mg} \mathrm{kg}^{-1}$ sonicated material. What this means is that nearly $2.4 \mathrm{~g}$ of $\mathrm{P}$ can potentially desorb of every kilogram of the agrichar when mixed in a solution containing $100 \mathrm{mg} \mathrm{P} \mathrm{L}^{-1}$. BG demonstrated a variable sorption capacity of $-41( \pm 133) \mathrm{mg} \mathrm{kg}^{-1}$ for the non-sonicated agrichar, and $-8( \pm 102) \mathrm{mg} \mathrm{kg}^{-1}$ for the sonicated agrichar. HB seemed to demonstrate a $S_{\max }$ of $699( \pm 77) \mathrm{mg} \mathrm{kg}^{-1}$ for the non-sonicated agrichar, and $644( \pm 113) \mathrm{mg} \mathrm{kg}^{-1}$ for the sonicated agrichar; whereas PF had $S_{\max }$ of $676( \pm 127) \mathrm{mg} \mathrm{kg}^{-1}$ for the non-sonicated agrichar, and $237( \pm 91) \mathrm{mg} \mathrm{kg}^{-1}$ for the sonicated agrichar. Sonication resulted in a significant reduction in $\mathrm{P}$ sorption maxima for PF agrichar only, which can be attributed to the increase in surface area of contact as a result of sonication (W. Y. Chen et al., 2014) and increased exposure of soluble $\mathrm{P}$ containing sites, which contributed back into the solution and lowered $\mathrm{S}_{\max }$. While both PF and $\mathrm{HB}$ can potentially act as $\mathrm{P}$ sinks due to higher total Ca content and relatively high $\mathrm{S}_{\max }$ values, it is critical to note that while wet sonication can increase CEC, it does not necessarily increase the P sorption capacity as demonstrated by PF agrichar. This could be because wet sonication may have resulted in separation of the finer material that would have otherwise help adsorb P. It is important to realize that ultimately P sorption dynamics is not simply a function of $\mathrm{CEC}$ alone, it also depends on the total $\mathrm{P}$ and major cations $(\mathrm{Ca}, \mathrm{Mg}, \mathrm{Fe}, \mathrm{Al})$ controlling its fate, as was observed in the case for RH and BG agrichar. 


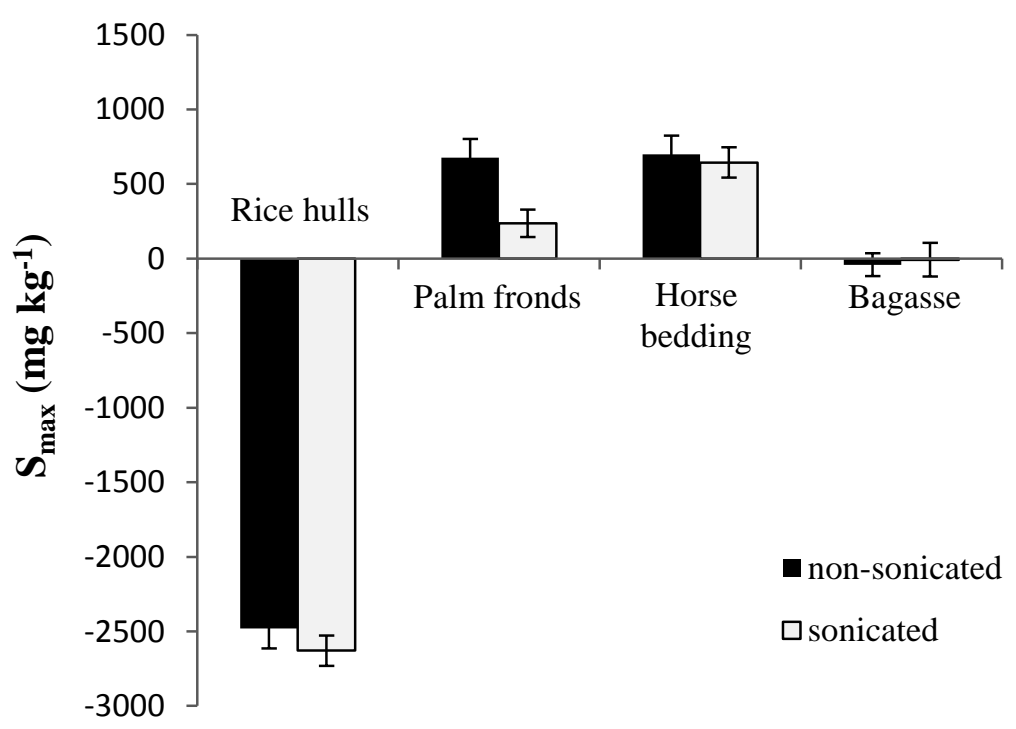

Figure 3. Maximum $P$ sorption capacity $\left(S_{\max }\right)$ of agrichars

\subsection{Adsorption and Desorption Potential of Agrichars}

Phosphorus sorption/desorption behavior over 57 days (1368 hours) of agrichars is shown in Figure 4. The initial concentration of $\mathrm{P}$ added to each treatment was $100 \mathrm{mg} \mathrm{L}^{-1}$. Phosphorus sorption dynamics was seen on two phase. Initially there was net release of $\mathrm{P}$ to solution by all agrichars up to 24 hours for non-sonicated samples and up to 4 days for sonicated samples. However, the net adsorption and desorption over full time of study varied by agrichar types. $\mathrm{RH}$ agrichar was the only sample with net desorption of $\mathrm{P}$ to the system even after a 57 day period. HB and PF agrichar samples showed overall net adsorption of added P; however, BG agrichar showed no overall adsorption or desorption of added $\mathrm{P}$ to solution at the end of 57 days. Phosphate interactions with soil and solution have been found to occur both ways, fast and slow. A two-step process with initial surface adsorption or desorption to surface followed by slow penetration or release by solid state diffusion (Barrow, 1983; J. S. Chen, Mansell, NkediKizza, \& Burgoa, 1996). Sonication was found to increase initial equilibrium period from 24 hours to almost 4 days. Phosphorus sorption and desorption trends were more consistent with EPC results than with $S_{\max }$ results. Initial total $\mathrm{P}$ and $\mathrm{Ca}$ concentration and their ratios was found to play significant roles on P sorption and desorption. Major cations found in soil like $\mathrm{Ca}, \mathrm{Fe}, \mathrm{Al}$ and $\mathrm{Mn}$ (Arai \& Sparks, 2007; Khatiwada, Hettiarachchi, Mengel, \& Fei, 2012; Lombi, McLaughlin, Johnston, Armstrong, \& Holloway, 2004; Shepherd, Joseph, Sohi, \& Heal, 2017) are found to act as active sorption site for phosphorus controlling its fate and mobility. Specifically for South Florida Histosols lying on limestone bedrock $\mathrm{CaCO}_{3}, \mathrm{Ca}$ is the most important cations controlling fate of P. Plant material derived from these soil condition would reflect the same trend.

Solution-phase phosphorus concentration (SPC) for non-sonicated and sonicated RH agrichar over 57 day period showed an overall increase over time. There was rapid net P desorption from HB over the first 24 hours, followed by slower desorption up to 57 days. Total $\mathrm{P}$ concentration for RH was inherently high $\left(12601 \mathrm{mg} \mathrm{kg}^{-1}\right.$ for non-sonicated and $11501 \mathrm{mg} \mathrm{kg}^{-1}$ for sonicated) and CEC is higher as well $\left(\sim 33 \mathrm{cmol}_{\mathrm{c}} \mathrm{kg}^{-1}\right)$ (Table 1). The CEC remained the same suggesting that the active sites of $\mathrm{P}$ sorption did not change due to sonication. Even though there was increase in total cations $(\mathrm{Ca}, \mathrm{Mg}, \mathrm{Fe}, \mathrm{Al})$ for sonicated samples, due to higher initial total $\mathrm{P}$ of the material, desorption occurred to maintain the system equilibrium. Specifically, total $\mathrm{Ca}$ to $\mathrm{P}$ ratio is lower as compared to PF and HB agrichars. The "slow" release of P remained more or less similar for sonicated versus non-sonicated RH agrichar. Due to higher initial total $\mathrm{P}$ concentration of $\mathrm{RH}$, the addition of $100 \mathrm{mg} \mathrm{kg}^{-1} \mathrm{P}$ would not have made any difference as the RH is already saturated with $\mathrm{P}$ and the release of $\mathrm{P}$ as seen on kinetics study can be contributed to its inherent $\mathrm{P}$ content, this was corroborated by the $\mathrm{S}_{\max }$ results. Consistent with the EPC data, RH had greatest EPC showing net desorption of P to the solution. Similar results have been found by (Dari et al., 2016) where addition of agrichar with EPC greater than that of system (soil) did not contribute to P retention at environmentally relevant solution $\mathrm{P}$ concentrations. Other researchers have found similar results with net release of P to solution from RH agrichars (Altland \& Locke, 2013; Pratiwi, Hillary, Fukuda, \& Shinogi, 2016). Altland \& Locke, 2013 found up to $35 \%$ of total P leached to the solution over the experiment duration 
for gasified RH agrichar. The effect of sonication does not seem to have any influence on rate of P desorption. Higher initial total P in chars have been found to decrease P adsorption (H. Z. Zhang et al., 2016).

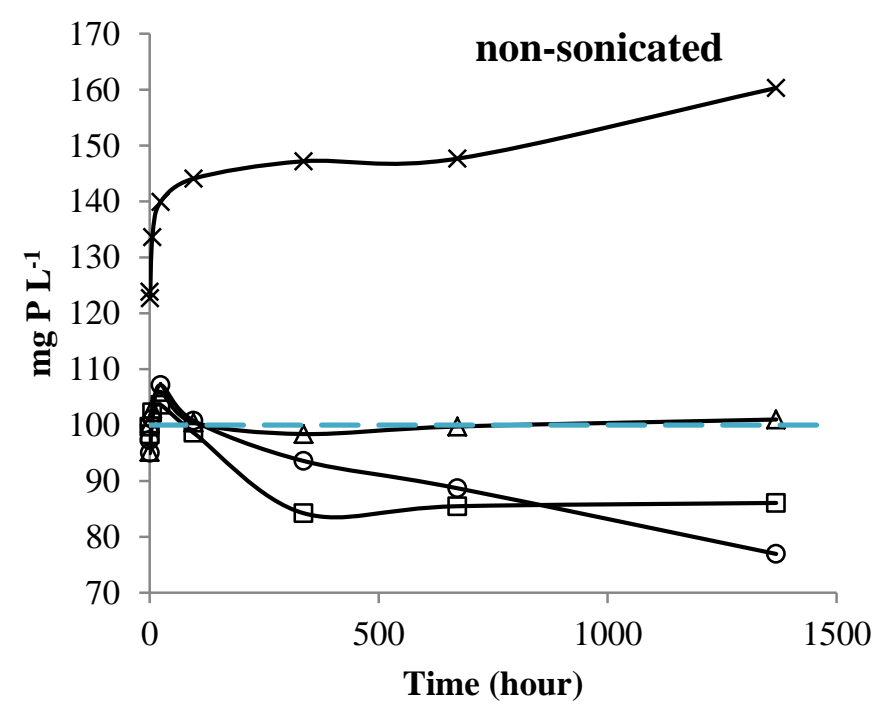

\section{(A)}

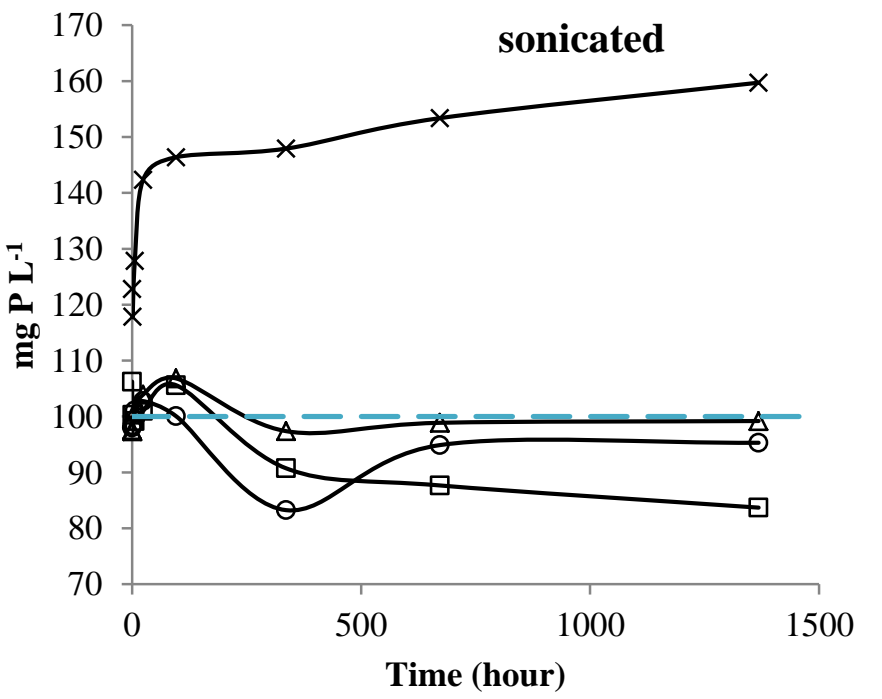

(B)

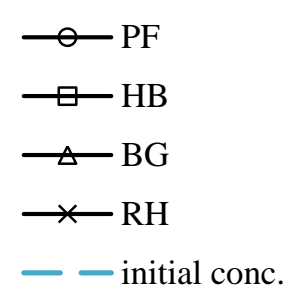

Figure 4. Phosphorus adsorption/desorption potential of agrichars over time (A) Non-sonicated, and (B) Sonicated agrichars

Solution-phase phosphorus concentration for non-sonicated HB agrichar over 57 day period showed a decreased over time. There was net desorption of $\mathrm{P}$ from $\mathrm{HB}$ agrichar for up to 24 hour but the system switched to sorption of $\mathrm{P}$ from solution to HB agrichar for up to 14 days. From 14 days to 28 days there was $\mathrm{P}$ desorbed from HB agrichar and ultimately the system stabilized up to 57 days period. At the end of 57 day period, nearly $15 \%$ of added $\mathrm{P}$ was adsorbed by non-sonicated HB agrichar. For sonicated HB agrichar, there was net desorption of $\mathrm{P}$ from solution for up to 24 hour but $\mathrm{P}$ was overall adsorbed over the 57 day period. At the end of 57 days, nearly $16 \%$ of added $\mathrm{P}$ was adsorbed by sonicated HB agrichar. The CEC of HB remained the same $\left(\sim 39 \mathrm{cmol}_{\mathrm{c}} \mathrm{kg}^{-1}\right)$ both before and after the sonication step, and we assume the surface active sites were not affected. Total $\mathrm{P}$ concentration of HB is relatively higher than other treatments except RH (Table 1). The results suggest P adsorption onto the HB agrichar despite their higher initial total $\mathrm{P}$ concentration and higher CEC which could be the function of higher total $\mathrm{Ca}$ and $\mathrm{Mg}$ concentration. These cations act as a sink for $\mathrm{P}$ and were in excess compared to total P concentration. Woody biochars have been known to adsorb P from solution and soils (Reddy, Xie, \& Dastgheibi, 2014; Vandecasteele, Reubens, Willekens, \& De Neve, 2014). Application of alkaline biochars have been found to significantly increase sorbed $\mathrm{P}$ and decrease the availability of sorbed $\mathrm{P}$ (Chintala et 
al., 2014). The result is consistent with observation seen by Reddy et al., (2014) on column experiment conducted with waste wood pellet biochar, which showed no leaching of any phosphorus during flushing concluding the biochar was not prone to release phosphorus leaching. Decrease in available P was also observed (Vandecasteele et al., 2014) for poultry manure blended with holm oak wood biochar in composts.

For sonicated PF samples, net P sorption occurred up to 14 days, followed by some $\mathrm{P}$ desorption up to 28 days, after which P sorption stabilized; the final P concentration reflected a net sorption of $<5 \%$ from the solution. Total $\mathrm{P}$ concentration of PF agrichar was 10 times lower as compared to RH and HB. Sonication seemed to have an effect on CEC and increased CEC from 27 to $41 \mathrm{cmol}_{\mathrm{c}} \mathrm{kg}^{-1}$ (Table 1). Net increase in CEC exposed otherwise inaccessible sites, which was seen in sonicated samples as net adsorption decreased from $25 \%$ to $5 \%$. PF had inherently high amount of total $\mathrm{Ca}$ and $\mathrm{Fe}$ associated with it and lower initial total $\mathrm{P}$ which favored sorption of $\mathrm{P}$. Mixed adsorption and desorption results have been found with pine biochar. Increased adsorption of $\mathrm{P}$ have been seen in experiment with pine biochar at concentrations $<100 \mathrm{mg} \mathrm{P} \mathrm{L}^{-1}(\mathrm{H}$. Z. Zhang et al., 2016) and Ponderosa pine residue biochar (Chintala et al., 2014). However, increased retention of $\mathrm{P}$ have been seen in experiment with pine biochar at concentrations $>200 \mathrm{mg} \mathrm{P} \mathrm{L}^{-1}$ (H. Z. Zhang et al., 2016).

Solution-phase $\mathrm{P}$ concentration for non-sonicated and sonicated BG agrichar remained relatively constant, with little sorption or desorption over the 57-day period. For BG, the CEC increased for sonicated samples; however, equilibrium $\mathrm{P}$ concentration did not change. Zhang et al. (2016) have found slight release of $\mathrm{P}$ into the solution from sugarcane bagasse biochar.

Phosphorus adsorption and desorption behavior indicate the ability of materials to adsorb or desorb P from the solution. For soils containing high P like peatland soils or muck soil (histosols), cultivation practices often tend to add sulfur to lower the $\mathrm{pH}$ rendering the nutrient bioavailable. The agrichars that showed higher affinity to adsorb P like HB agrichar could be used in those scenarios to limit the loss of excess $\mathrm{P}$ in solution (Ying Yao et al., 2013; Ying Yao et al., 2011). Whereas, sandy soils with lower soil test P, application of P desorbing agrichars like RH and BG would help increase bioavailable pool of $\mathrm{P}$ by limiting adsorption; virtually acting as a slow release $\mathrm{P}$ fertilizer.

\section{Conclusions}

Results from this study shows that torrefied agricultural byproducts can be used as a source as well as a sink of phosphorus in agroecosystems. Their behavior in aqueous solution was found to be dependent on the type of material used for agrichar production and to a small extent its cation exchange capacity. RH agrichar showed desorption of $\mathrm{P}$ to the solution indicating it could serve as a slow $\mathrm{P}$ releasing amendment. PF and HB agrichar showed high affinity for $\mathrm{P}$ in solution and could be used to capture excess $\mathrm{P}$ from sandy soils that have a tendency to leach nutrients. Sugarcane BG agrichar was found to have a very limited effect on $\mathrm{P}$ sorption dynamics. Our results suggest sugarcane bagasse agrichar had slight initial release of $\mathrm{P}$ during the first 24 hours, but reached equilibrium with no net $\mathrm{P}$ adsorption or desorption at the end of 57 days. Sonication was found to have a variable effect on $\mathrm{P}$ sorption dynamics, due to the compounding effects of other physicochemical parameters. Initial P content of the agrichar seemed to have an overriding effect on the P sorption behavior of the agrichar. As sustainable agricultural practices are being investigated to improve soil health, further research on the effects of physicochemical parameters of agrichars to agroecosystem services is warranted.

\section{Acknowledgments}

The authors would like to thank Sugar Cane Growers Cooperative and Sem Chi Rice Products Corps for providing bagasse and rice hulls respectively, that was used in this study. The authors would also like to thank graduate student Mohsen Tootoonchi for helping with CEC analyses. This research was funded by the University of Florida Institute of Food and Agricultural Sciences, and USDA Hatch Project 1011385. Project number: FLA-ERC-005552.

\section{References}

Altland, J. E., \& Locke, J. C. (2013). Effect of Biochar Type on Macronutrient Retention and Release from Soilless Substrate. Hortscience, 48(11), 1397-1402.

Arai, Y., \& Sparks, D. L. (2007). Phosphate reaction dynamics in soils and soil components: A muiltiscale approach. Advances in Agronomy, 94, 135-179. https://doi.org/10.1016/S0065-2113(06)94003-6

Azargohar, R., \& Dalai, A. K. (2008). Steam and KOH activation of biochar: Experimental and modeling studies. Microporous and Mesoporous Materials, 110(2-3), 413-421.

https://doi.org/10.1016/j.micromeso.2007.06.047 
Barrow, N. J. (1983). A mechanistic model for describing the sorption and desorption of phosphate by soil. Journal of Soil Science, 34(4), 733-750. https://doi.org/10.1111/j.1365-2389.1983.tb01068.x

Bhadha, J. H., Jennewein, S., Sanchez, J., \& Lang, T. (2014). Producing Biochar using a custom designed Top-lit Updraft (TLUD) gasifier (Vol. SL413): University of Florida IFAS, EDIS Publication.

Castillo, A. E., Benito, S. G., \& Fernandez, J. A. (2003). Using organic manures as liming materials. Agrochimica, 47(1-2), 14-20.

Chen, J. S., Mansell, R. S., NkediKizza, P., \& Burgoa, B. A. (1996). Phosphorus transport during transient, unsaturated water flow in an acid sandy soil. Soil Science Society of America Journal, 60(1), 42-48. https://doi.org/10.2136/sssaj1996.03615995006000010009x

Chen, W. Y., Mattern, D. L., Okinedo, E., Senter, J. C., Mattei, A. A., \& Redwine, C. W. (2014). Photochemical and Acoustic Interactions of Biochar with $\mathrm{CO} 2$ and $\mathrm{H} 2 \mathrm{O}$ : Applications in Power Generation and $\mathrm{CO} 2$ Capture. Aiche Journal, 60(3), 1054-1065. https://doi.org/10.1002/aic.14347

Chintala, R., Schumacher, T. E., McDonald, L. M., Clay, D. E., Malo, D. D., Papiernik, S. K., et al. (2014). Phosphorus Sorption and Availability from Biochars and Soil/Biochar Mixtures. Clean-Soil Air Water, 42(5), 626-634. https://doi.org/10.1002/clen.201300089

Dari, B., Nair, V. D., Harris, W. G., Nair, P. K. R., Sollenberger, L., \& Mylavarapu, R. (2016). Relative influence of soil- vs. biochar properties on soil phosphorus retention. Geoderma, 280, 82-87. https://doi.org/10.1016/j.geoderma.2016.06.018

Ding, Y., Liu, Y. G., Liu, S. B., Li, Z. W., Tan, X. F., Huang, X. X., et al. (2016). Biochar to improve soil fertility. A review. Agronomy for Sustainable Development, 36(2). https://doi.org/10.1007/s13593-016-0372-z

Gao, S., Hoffman-Krull, K., Bidwell, A. L., \& DeLuca, T. H. (2016). Locally produced wood biochar increases nutrient retention and availability in agricultural soils of the San Juan Islands, USA. Agriculture Ecosystems \& Environment, 233, 43-54. https://doi.org/10.1016/j.agee.2016.08.028

Glaser, B., Lehmann, J., \& Zech, W. (2002). Ameliorating physical and chemical properties of highly weathered soils in the tropics with charcoal - a review. Biology and Fertility of Soils, 35(4), 219-230. https://doi.org/10.1007/s00374-002-0466-4

Ippolito, J. A., Ducey, T. F., Cantrell, K. B., Novak, J. M., \& Lentz, R. D. (2016). Designer, acidic biochar influences calcareous soil characteristics. Chemosphere, 142, 184-191. https://doi.org/10.1016/j.chemosphere.2015.05.092

Jing, X. R., Wang, Y. Y., Liu, W. J., Wang, Y. K., \& Jiang, H. (2014). Enhanced adsorption performance of tetracycline in aqueous solutions by methanol-modified biochar. Chemical Engineering Journal, 248, 168-174. https://doi.org/10.1016/j.cej.2014.03.006

Khatiwada, R., Hettiarachchi, G. M., Mengel, D. B., \& Fei, M. W. (2012). Speciation of Phosphorus in a Fertilized, Reduced-Till Soil System: In-Field Treatment Incubation Study. Soil Science Society of America Journal, 76(6), 2006-2018. https://doi.org/10.2136/sssaj2011.0299

Lim, J. L., \& Okada, M. (2005). Regeneration of granular activated carbon using ultrasound. Ultrasonics Sonochemistry, 12(4), 277-282. https://doi.org/10.1016/j.ultsonch.2004.02.003Lin, Y., Munroe, P., Joseph, S., Henderson, R., \& Ziolkowski, A. (2012). Water extractable organic carbon in untreated and chemical treated biochars. Chemosphere, 87(2), 151-157. https://doi.org/10.1016/j.chemosphere.2011.12.007

Lombi, E., McLaughlin, M. J., Johnston, C., Armstrong, R. D., \& Holloway, R. E. (2004). Mobility and lability of phosphorus from granular and fluid monoammonium phosphate differs in a calcareous soil. Soil Science Society of America Journal, 68(2), 682-689. https://doi.org/10.2136/sssaj2004.6820

Madiba, O. F., Solaiman, Z. M., Carson, J. K., \& Murphy, D. V. (2016). Biochar increases availability and uptake of phosphorus to wheat under leaching conditions. Biology and Fertility of Soils, 52(4), 439-446. https://doi.org/10.1007/s00374-016-1099-3

Major, J., Rondon, M., Molina, D., Riha, S. J., \& Lehmann, J. (2010). Maize yield and nutrition during 4 years after biochar application to a Colombian savanna oxisol. Plant and Soil, 333(1-2), 117-128. https://doi.org/10.1007/s11104-010-0327-0

Manya, J. J. (2012). Pyrolysis for Biochar Purposes: A Review to Establish Current Knowledge Gaps and Research Needs. Environmental Science \& Technology, 46(15), 7939-7954. https://doi.org/10.1021/es301029g 
Mylavarapu, R. S., \& Moon, D. L. (2002). UF/IFAS Extension Soil Testing Laboratory (ESTL) Analytical Procedures and Training Manual. (Vol. Circular 1248.): Soil and Water Sciences Department, Florida.Cooperative Extension Service, Institute of Food and Agricultural Sciences, University of Florida.

Ngatia, L. W., Hsieh, Y. P., Nemours, D., Fu, R., \& Taylor, R. W. (2017). Potential phosphorus eutrophication mitigation strategy: Biochar carbon composition, thermal stability and $\mathrm{pH}$ influence phosphorus sorption. [Article]. Chemosphere, 180, 201-211. https://doi.org/10.1016/j.chemosphere.2017.04.012

Perez-Esteban, J., Escolastico, C., Masaguer, A., \& Moliner, A. (2012). Effects of sheep and horse manure and pine bark amendments on metal distribution and chemical properties of contaminated mine soils. [Article]. European Journal of Soil Science, 63(5), 733-742. https://doi.org/10.1111/j.1365-2389.2012.01468.x

Pratiwi, E. P. A., Hillary, A. K., Fukuda, T., \& Shinogi, Y. (2016). The effects of rice husk char on ammonium, nitrate and phosphate retention and leaching in loamy soil. Geoderma, 277, 61-68. https://doi.org/10.1016/j.geoderma.2016.05.006

Qian, K. Z., Kumar, A., Zhang, H. L., Bellmer, D., \& Huhnke, R. (2015). Recent advances in utilization of biochar. Renewable \& Sustainable Energy Reviews, 42, 1055-1064. https://doi.org/10.1016/j.rser.2014.10.074

Rajapaksha, A. U., Chen, S. S., Tsang, D. C. W., Zhang, M., Vithanage, M., Mandal, S., et al. (2016). Engineered/designer biochar for contaminant removal/immobilization from soil and water: Potential and implication of biochar modification. Chemosphere, 148, 276-291. https://doi.org/10.1016/j.chemosphere.2016.01.043

Rajapaksha, A. U., Vithanage, M., Ahmad, M., Seo, D. C., Cho, J. S., Lee, S. E., et al. (2015). Enhanced sulfamethazine removal by steam-activated invasive plant-derived biochar. Journal of Hazardous Materials, 290, 43-50. https://doi.org/10.1016/j.jhazmat.2015.02.046

Randolph, P., Bansode, R. R., Hassan, O. A., Rehrah, D., Ravella, R., Reddy, M. R., et al. (2017). Effect of biochars produced from solid organic municipal waste on soil quality parameters. Journal of Environmental Management, 192, 271-280. https://doi.org/10.1016/j.jenvman.2017.01.061

Rao, P. S. C., \& Davidson, J. M. (1979). Adsorption and movement of selected pesticides at high-concentrations in soils. Water Research, 13(4), 375-380. https://doi.org/10.1016/0043-1354(79)90026-5

Reddy, K. R., Wang, Y., DeBusk, W. F., Fisher, M. M., \& Newman, S. (1998). Forms of soil phosphorus in selected hydrologic units of the Florida everglades. Soil Science Society of America Journal, 62(4), 1134-1147. https://doi.org/10.2136/sssaj1998.03615995006200040039x

Reddy, K. R., Xie, T., \& Dastgheibi, S. (2014). Evaluation of Biochar as a Potential Filter Media for the Removal of Mixed Contaminants from Urban Storm Water Runoff. Journal of Environmental Engineering, 140, 04014043, 1-12(12). https://doi.org/10.1061/(asce)ee.1943-7870.0000872

Shepherd, J. G., Joseph, S., Sohi, S. P., \& Heal, K. V. (2017). Biochar and enhanced phosphate capture: Mapping mechanisms to functional properties. [Article]. Chemosphere, 179, 57-74. https://doi.org/10.1016/j.chemosphere.2017.02.123

Stankovich, S., Dikin, D. A., Dommett, G. H. B., Kohlhaas, K. M., Zimney, E. J., Stach, E. A., et al. (2006). Graphene-based composite materials. Nature, 442(7100), 282-286. https://doi.org/10.1038/nature04969

Streubel, J. D., Collins, H. P., Garcia-Perez, M., Tarara, J., Granatstein, D., \& Kruger, C. E. (2011). Influence of Contrasting Biochar Types on Five Soils at Increasing Rates of Application. Soil Science Society of America Journal, 75(4), 1402-1413. https://doi.org/10.2136/sssaj2010.0325

Sumner, M. E., \& Miller, W. P. (1996). Cation exchange capacity and exchange coefficient. (Vol. SSSA Book Series no. 5, pp. 1201-1230). Madison, Wisconsin.: In Sparks (ed) Methods of soil analysis, part 3: Chemical Methods.

Thomas, G.W. (1996). Soil pH and Soil Acidity. (Vol. In Sparks (ed) Methods of soil analysis, part 3: Chemical Methods. SSSA Book Series no. 5, pp. 475-490). Madison, Wisconsin.

Uchimiya, M., Wartelle, L. H., Klasson, K. T., Fortier, C. A., \& Lima, I. M. (2011). Influence of Pyrolysis Temperature on Biochar Property and Function as a Heavy Metal Sorbent in Soil. Journal of Agricultural and Food Chemistry, 59(6), 2501-2510. https://doi.org/10.1021/jf104206c 
Van Zwieten, L., Singh, B. P., Joseph, S., Kimber, S., Cowie, A., \& Chan, K. Y. (2009). Biochar and emissions of non-CO2 greenhouse gases from soil. 227-249.

Vandecasteele, B., Reubens, B., Willekens, K., \& De Neve, S. (2014). Composting for Increasing the Fertilizer Value of Chicken Manure: Effects of Feedstock on P Availability. Waste and Biomass Valorization, 5(3), 491-503. https://doi.org/10.1007/s12649-013-9264-5

Vithanage, M., Rajapaksha, A. U., Zhang, M., Thiele-Bruhn, S., Lee, S. S., \& Ok, Y. S. (2015). Acid-activated biochar increased sulfamethazine retention in soils. Environmental Science and Pollution Research, 22(3), 2175-2186. https://doi.org/10.1007/s11356-014-3434-2

Wang, X. X., Qiu, Z. F., Lu, S. G., \& Ying, W. C. (2010). Characteristics of organic, nitrogen and phosphorus species released from ultrasonic treatment of waste activated sludge. [Article]. Journal of Hazardous Materials, 176(1-3), 35-40. https://doi.org/10.1016/j.jhazmat.2009.10.115

Windeatt, J. H., Ross, A. B., Williams, P. T., Forster, P. M., Nahil, M. A., \& Singh, S. (2014). Characteristics of biochars from crop residues: Potential for carbon sequestration and soil amendment. Journal of Environmental Management, 146, 189-197. https://doi.org/10.1016/j.jenvman.2014.08.003

Yao, Y., Gao, B., Chen, J., \& Yang, L. (2013). Engineered Biochar Reclaiming Phosphate from Aqueous Solutions: Mechanisms and Potential Application as a Slow-Release Fertilizer. Environmental Science \& Technology, 47(15), 8700-8708. https://doi.org/10.1021/es4012977

Yao, Y., Gao, B., Inyang, M., Zimmerman, A. R., Cao, X., Pullammanappallil, P., et al. (2011). Removal of phosphate from aqueous solution by biochar derived from anaerobically digested sugar beet tailings. Journal of Hazardous Materials, 190(1-3), 501-507. https://doi.org/10.1016/j.jhazmat.2011.03.083

Yao, Y., Gao, B., Zhang, M., Inyang, M., \& Zimmerman, A. R. (2012). Effect of biochar amendment on sorption and leaching of nitrate, ammonium, and phosphate in a sandy soil. Chemosphere, 89(11), 1467-1471. https://doi.org/10.1016/j.chemosphere.2012.06.002

Zhang, H. Z., Chen, C. R., Gray, E. M., Boyd, S. E., Yang, H., \& Zhang, D. K. (2016). Roles of biochar in improving phosphorus availability in soils: A phosphate adsorbent and a source of available phosphorus. Geoderma, 276, 1-6. https://doi.org/10.1016/j.geoderma.2016.04.020

Zhang, X. N., Mao, G. Y., Jiao, Y. B., Shang, Y., \& Han, R. P. (2014). Adsorption of anionic dye on magnesium hydroxide-coated pyrolytic bio-char and reuse by microwave irradiation. International Journal of Environmental Science and Technology, 11(5), 1439-1448. https://doi.org/10.1007/s13762-013-0338-5

Zhang, X., Zhang, S. H., Yang, H. P., Shi, T., Chen, Y. Q., \& Chen, H. P. (2013). Influence of NH3/CO2 Modification on the Characteristic of Biochar and the CO2 Capture. Bioenergy Research, 6(4), 1147-1153. https://doi.org/10.1007/s12155-013-9304-9

Zhu, Q. H., Peng, X. H., \& Huang, T. Q. (2015). Contrasted effects of biochar on maize growth and N use efficiency depending on soil conditions. International Agrophysics, 29(2), 257-266. https://doi.org/10.1515/intag-2015-0023

\section{Copyrights}

Copyright for this article is retained by the author(s), with first publication rights granted to the journal.

This is an open-access article distributed under the terms and conditions of the Creative Commons Attribution license (http://creativecommons.org/licenses/by/3.0/). 